\title{
Feasibility of Rubber+Tea Intercropping during Immature Phase of Rubber
}

\author{
R.S. Singh*, T. Gohain, S. Meti, D. Choudhuri, R.P. Singh, M.A. Nazeer and J. Jacob \\ Tirhut College of Agriculture, Dholi; Dr. Rajendra Prasad Central Agricultural University, \\ Pusa (Bihar), India \\ *Corresponding author
}

\begin{tabular}{l} 
Key w or d s \\
$\begin{array}{l}\text { Rubber, Immature } \\
\text { phase, Tea, } \\
\text { Intercropping, Red } \\
\text { spider mite }\end{array}$ \\
Article Info \\
$\begin{array}{l}\text { Accepted: } \\
\text { 15 February } 2019 \\
\text { Available Online: } \\
\text { 10 March } 2019\end{array}$ \\
\hline
\end{tabular}

\section{Keywords}

Rubber, Immature phase, Tea, Intercropping, Red

Accepted:

\section{A B S T R A C T}

An experiment of rubber plants intercropped with tea was conducted at the Regional Experiment Station, Nagrakata, Jalpaiguri district of West Bengal to see the feasibility of growing tea as intercrop with rubber in Dooars area of north Bengal. It can be concluded that tea can successfully be grown as beneficial intercrop in between the inter-row spaces of rubber by changing in the crop geometry during immature phase of rubber with additional benefit of less attack of red spider mite to tea crop/leaf. Growth (girth) of rubber was significantly superior under intercropped treatments $\left(T_{3} \& T_{5}\right)$ than pure rubber stand $\left(T_{1}\right)$ while girth of tea plants was found at par in all the treatments. Green tea leaf yield at $100 \%$ population of tea under pure tea stand was found significantly superior than the green tea leaf yields in all the intercropped treatments but at $100 \%$ plant population of tea, all treatments were found equally good with pure tea stand. Remunerative index values of different intercropping systems varied from 1.57 to 1.94 . Infestation by red spider mite Oligonychus coffeae Nietner) was found significantly lower in all intercropped treatments than pure tea stand of tea.

\section{Introduction}

With the objectives to generate income and employment during immature phase of rubber, to utilize inter-row spaces between rubber rows, to enhance resource use efficiency and more importantly, to provide insurance against crop/plant damages/failures (damages caused by wind, diseases, insect-pests) and price fluctuations of both the crops which is beyond the control of the farmers; an experiment was initiated at the Regional Experiment Station,
Nagrakata, Jalpaiguri district of West Bengal. Originally, the main objective of this experiment was to test the feasibility of intercropping rubber with tea in Dooars area of West Bengal.

Dooars area of West Bengal is mainly a tea growing belt and hence, it was not easy/wise to convince the farmers of this region to go for rubber plantation in place of tea due to several social, environmental and socio-economic factors but to convince them for using rubber 
as shade trees for tea without any adverse effect on tea with an additional benefit of rubber yield on a negligible cost of cultivation for rubber as compared to tea and also to get an attractive timber value of rubber plants in the last; will be comparatively easy and wise. It will be an example of environmental symbiosis with natural diversification. About 461 hectares of area is under rubber cultivation in West Bengal that could further be expanded by this method in this type nontraditional area.

\section{Materials and Methods}

Regional Experiment Station, Nagrakata, Jalpaiguri district of West Bengal is situated at $56^{\circ} 54^{\prime} \mathrm{N}$ latitude and $88^{\circ} 25^{\prime}$ longitude with an elevation of 229 meters above mean sea level and falls under northern parts of West Bengal near Sikkim State and Bhutan border. Soil of the experimental plot is well drained sandy loam, acidic in reaction $(\mathrm{pH} ; 4.0$ - 4.5), high in organic carbon and low in available phosphorus and potash content. Climate of this region as been characterized as humid tropics with an annual rainfall of more than $3200 \mathrm{~mm}$ of which about $80 \%$ of rainfall comes during five months (May to September) and having highest in the month of July.

Experiment was laid out in randomized block design with four replications. Planting material of rubber was RRII 105 and that of tea was TV-23. Plot size was kept $45 \mathrm{~m}$ X 20 $\mathrm{m}$. Rubber and tea was planted in the year 1999 and 2000, respectively. There were six treatments including two sole crops of rubber and tea planted at their normal spacing of 5.0 $\mathrm{X} \quad 5.0 \mathrm{~m} \quad\left(\mathrm{~T}_{1}\right)$ and $1.0 \quad \mathrm{X} \quad 0.6 \mathrm{~m} \quad\left(\mathrm{~T}_{6}\right)$, respectively. Remaining four treatments of rubber + tea intercropping with varying spacing of rubber were $10.0 \times 2.5 \mathrm{~m}\left(\mathrm{~T}_{2}\right)$, 12.0 X $2.5 \mathrm{~m}\left(\mathrm{~T}_{3}\right), 3.0 / 18.0 \times 3.0 \mathrm{~m}$ - paired row planting $\left(\mathrm{T}_{4}\right)$ and $10.0 \times 5.0 \mathrm{~m}\left(\mathrm{~T}_{5}\right)$ with normal spacing of tea in all the treatments. All the standard package of practices of rubber and tea were followed as per the recommendation of Rubber Research Institute of India, Kottayam (Kerala) and Tea Research Association, Nagrakata (West Bengal). Remunerative index (R.I.) as per Willey and Osiru (1972) was worked out as below-

R.I. $=$

Average girth of rubber in mixture Yield of intercrop in mixture

Average girth of rubber in pure stand Yield of intercrop in pure stand

\section{Results and Discussion}

Growth performance of rubber in terms of girth attainment was almost similar in all the treatments except $T_{3}$ and $T_{5}$ (Table 1) in which girth of rubber was significantly higher than all the treatments. This may simply be due to better availability of growth factors from the both below and above the soil surface and also due to less competition for the same. Minimum girth attainment was recorded in $\mathrm{T}_{4}$ due to less availability of growth factors from the both below and above the soil surface and also due to more competition for the growth factors by the rubber plants (Kakaty et al., 2002). This clearly indicates that there is no adverse effect on rubber plants due to intercropping of tea in between the inter-row spaces of rubber plants. Effect of intercropping tea with rubber has no negative impact on tea growth (girth) in different intercropped treatments. Girth of tea plants in all other treatments was found at par implying rubber had not an adverse effect on tea girth.

Annual girth increment of rubber shows that girth increment in pure rubber stand was at par with other treatments intercropped with tea except in $T_{4}$ where close planting space of rubber resulted in high competition for 
nutrients (above and below soil factors) which in turn resulted in minimum girth increment. This indicates that there was no adverse effect on girth increment of rubber due to intercropped tea and in fact, it was maximum in $\mathrm{T}_{5}$ where rubber was intercropped with tea but annual girth increment in tea does not follow the same trend as was recorded in rubber. Although, it was found nonsignificant, all the treatments of intercropping recorded higher value of girth increment than pure tea stand. This also implies that there was no adverse effect of rubber association on girth increment of tea and in fact, it was found maximum in $\mathrm{T}_{4}$ and minimum in pure tea stand.

Green tea leaf yield (' $000 \mathrm{~kg} / \mathrm{ha}$ ) during all the four years were found significantly higher under pure tea stand than all other intercropping treatments with less than $100 \%$ plant population which was obviously due to higher plant population per hectare (Table 2) but when the yield was calculated on the basis of 100 per cent plant population under different treatments, it was found nonsignificant in all the four years and during the first three years, yield of green tea leaf was higher in all the intercropping treatments than pure tea which may be due to better utilization of resources during the initial three years. During the first two years of green tea leaf yield, $\mathrm{T}_{4}$ recorded minimum yield but from third year onwards, the yield was maximum under $\mathrm{T}_{4}$ treatment as compared to other intercropping treatments which may be due to better availability and efficient utilization of growth factors specially above ground factors. Monthly yield variation of green tea leaf had also some bearing on rubber + tea intercropping systems. The whole yielding period (March,04 to December, 04) can be divided into two parts. A closer look on monthly yield variation (Table 3 ) revealed that green tea leaf yield in pure tea stand was manifold as compared to other intercropping treatments from June to October but from March to May there was reduction in yield in pure tea stand which may be due to severe attack/infestation of red spider mite in pure tea stand. Red spider mite is known to attack easily to those tea plant leaves which are more exposed to sun, having high temperature and getting more dust deposition. It was for the first time reported in the world by me in 2004 during Annual Review Meeting of the Rubber Research Institute of India, Kottayam, Kerala that due to rubber plants used as shade tree in rubber + tea intercropping system, infestation of red spider mite was significantly less in all the intercropped treatments than pure tea stand. Yield variation of green tea leaf was also recorded and at was found that the peak period for green tea leaf was the month of June in all the intercropped stands but for pure tea stand the peak period for green tea leaf was the month of August followed by June, October and July.

Value of remunerative index (1.57-1.94) of different intercropping treatments also proved that rubber + tea intercropping system is more beneficial than the pure stand of rubber and tea (Table 4). Remunerative index is based on the LER of Willey and Osiru (1972) and used to quantify the beneficial effect of intercropping systems where one crop is under immature stage while the other one is under yielding stage. Mortality of rubber plants mainly by wind (Table 4) had been significantly affected in different intercropping treatments and it was significantly higher in $T_{5}$ as compared to $T_{1}$ and $\mathrm{T}_{3}$ may be due to not getting proper support of neighbouring rubber plants during high wind because of higher inter-row spaces. It was significantly minimum in pure rubber stand (T1) followed by $T_{3}$ than $T_{5}$ which might be due to neighbouring support of rubber plants during high winds clearly because of the less inter-row spaces between rubber plants. Although, the girth and 
remunerative index were highest in $T_{5}$, plant population and mortality of main crop (rubber) were lowest and highest, respectively in $\mathrm{T}_{5}$ which indicates that it can't be adopted. Infestation by red spider mite was also recorded and it was found significantly higher in pure tea stand than all other intercropped treatments may be due to high temperature (Choudhury et al., 2006) (Fig. 1 and 2).

Table.1 Growth/girth of rubber and tea

\begin{tabular}{|c|c|c|c|c|c|c|c|}
\hline \multirow[t]{2}{*}{ Treatments } & \multicolumn{2}{|c|}{ RUBBER } & \multicolumn{5}{|c|}{ TEA } \\
\hline & $\begin{array}{l}\text { Girth } \\
(\mathrm{cm}) \\
2004\end{array}$ & $\begin{array}{l}\text { Annual } \\
\text { girth } \\
\text { increment } \\
\text { (cm) } 2004\end{array}$ & $\begin{array}{l}\text { Girth } \\
(\mathrm{cm}) \\
2004\end{array}$ & $\begin{array}{l}\text { Annual } \\
\text { girth } \\
\text { increment } \\
\text { (cm) } 2004\end{array}$ & $\begin{array}{l}\text { Number of } \\
\text { primary } \\
\text { branches } \\
\text { /plant(2004) }\end{array}$ & $\begin{array}{l}\text { Number of } \\
\text { secondary } \\
\text { branches } \\
\text { /plant(2004) }\end{array}$ & $\begin{array}{l}\text { Number of } \\
\text { tertiary } \\
\text { branches } \\
\text { /plant }\end{array}$ \\
\hline $\begin{array}{l}\mathrm{T}_{1} \text {-Pure rubber }(5.0 \\
\text { X } 5.0 \mathrm{~m})\end{array}$ & 36.20 & 6.38 & ---- & ---- & ---- & --- & --- \\
\hline $\begin{array}{l}\mathrm{T}_{2}-(\mathrm{R}+\mathrm{T}) \\
(10.0 \times 2.5 \mathrm{~m})\end{array}$ & 36.06 & 5.16 & 13.02 & 1.03 & 2.88 & 11.75 & 24.69 \\
\hline $\begin{array}{l}\mathrm{T}_{3}-(\mathrm{R}+\mathrm{T}) \\
(12.0 \times 2.5 \mathrm{~m})\end{array}$ & 40.52 & 5.75 & 12.87 & 0.99 & 2.75 & 12.75 & 24.38 \\
\hline $\begin{array}{l}\mathrm{T}_{4}-(\mathrm{R}+\mathrm{T}) \\
(3 / 18 \times 3.0 \mathrm{~m})\end{array}$ & 35.73 & 4.48 & 13.43 & 1.46 & 3.31 & 12.38 & 26.19 \\
\hline $\begin{array}{l}\mathrm{T}_{5}-(\mathrm{R}+\mathrm{T}) \\
(10.0 \times 5.0 \mathrm{~m})\end{array}$ & 42.70 & 6.94 & 13.86 & 1.22 & 3.31 & 12.06 & 25.56 \\
\hline $\begin{array}{l}\mathrm{T}_{6}-\text { Pure tea } \\
(1.0 \times 0.6 \mathrm{~m})\end{array}$ & ---- & ---- & 13.60 & 0.88 & 3.19 & 13.19 & 27.88 \\
\hline $\mathrm{CD}(\mathrm{p}=0.05)$ & 3.96 & 0.98 & 1.01 & 0.60 & 0.73 & 2.69 & 3.82 \\
\hline
\end{tabular}

Table.2 Yield ('000 kg/ha) of green tea leaf

\begin{tabular}{|l|c|c|c|c|}
\hline Treatments & 2001 & 2002 & 2003 & 2004 \\
\hline $\mathrm{T}_{1}$ - Pure rubber & ---- & ---- & --- & ---- \\
$(5.0$ X 5.0 m) & 1.224 & 3.329 & 4.866 & 7.396 \\
\hline $\mathrm{T}_{2}-(\mathrm{R}+\mathrm{T})$ & $(2.40)$ & $(5.548)$ & $(8.110)$ & $(12.326)$ \\
$(10.0$ X 2.5 m) & 1.276 & 3.351 & 4.820 & 7.573 \\
\hline $\mathrm{T}_{3}-(\mathrm{R}+\mathrm{T})$ & $(1.994)$ & $(5.237)$ & $(7.531)$ & $(11.832)$ \\
$(12.0$ X 2.5 m) & 1.218 & 3.289 & 5.318 & 7.804 \\
\hline $\mathrm{T}_{4}-(\mathrm{R}+\mathrm{T})$ & $(1.876)$ & $(5.061)$ & $(8.182)$ & $(12.006)$ \\
$(3 / 18$ X 3.0 m) & 1.245 & 3.189 & 4.972 & 7.529 \\
\hline $\mathrm{T}_{5}-(\mathrm{R}+\mathrm{T})$ & $((2.074)$ & $(5.316)$ & $(8.286)$ & $(12.549)$ \\
$(10.0$ X 5.0 m) & 1.834 & 4.651 & 7.538 & 12.833 \\
\hline $\mathrm{T}_{6}-$ Pure tea & $(18.34)$ & $(46.51)$ & $(75.38)$ & $(12.833)$ \\
$(1.0$ X 0.6 m) & 0.287 & 0.582 & 0.503 & 1.394 \\
\hline $\mathrm{CD}(\mathrm{p}=0.05)$ & $(0.372)$ & $(0.602)$ & $(0.683)$ & $(1.856)$ \\
\hline
\end{tabular}

Note: Figures given in the parentheses is yield of green tea leaf (' $000 \mathrm{~kg} / \mathrm{ha}$ ) at $100 \%$ plant population 
Table.3 Monthly yield ('000 kg/ha) variation of green tea leaf

\begin{tabular}{|c|c|c|c|c|c|c|c|c|c|c|c|}
\hline $\begin{array}{l}\text { Months } \\
\text { Treatments }\end{array}$ & Mar,04 & Apr,04 & May,04 & Jun,04 & Jul,04 & Aug,04 & Sept04 & Oct,04 & Nov,04 & Dec,04 & Total \\
\hline $\begin{array}{l}T_{1} \text { - Pure rubber } \\
(5.0 \times 5.0 \mathrm{~m})\end{array}$ & ---- & --- & --- & --- & ---- & ---- & ---- & ---- & ---- & --- & --- \\
\hline $\begin{array}{l}\mathrm{T}_{2}-(\mathrm{R}+\mathrm{T}) \\
(10.0 \times 2.5 \mathrm{~m})\end{array}$ & $\begin{array}{c}1.057 \\
(1.761)\end{array}$ & $\begin{array}{c}0.059 \\
0.098)\end{array}$ & $\begin{array}{c}0.357 \\
(0.594)\end{array}$ & $\begin{array}{c}1.487 \\
(2.477)\end{array}$ & $\begin{array}{c}1.093 \\
(1.822)\end{array}$ & $\begin{array}{c}1.256 \\
(2.092)\end{array}$ & $\begin{array}{c}0.711 \\
(1.185)\end{array}$ & $\begin{array}{c}0.887 \\
(1.477)\end{array}$ & $\begin{array}{c}0.398 \\
(0.662)\end{array}$ & $\begin{array}{c}0.094 \\
(0.157)\end{array}$ & $\begin{array}{c}7.398 \\
(12.329)\end{array}$ \\
\hline $\begin{array}{l}\mathrm{T}_{3}-(\mathrm{R}+\mathrm{T}) \\
(12.0 \times 2.5 \mathrm{~m})\end{array}$ & $\begin{array}{c}0.982 \\
(1.534)\end{array}$ & $\begin{array}{c}0.103 \\
(0.161)\end{array}$ & $\begin{array}{c}0.370 \\
(0.578)\end{array}$ & $\begin{array}{c}1.487 \\
(2.322)\end{array}$ & $\begin{array}{c}1.131 \\
(1.767)\end{array}$ & $\begin{array}{c}1.276 \\
(1.993)\end{array}$ & $\begin{array}{c}0.749 \\
(1.170)\end{array}$ & $\begin{array}{c}0.949 \\
(1.482)\end{array}$ & $\begin{array}{c}0.440 \\
(0.687)\end{array}$ & $\begin{array}{c}0.122 \\
(0.190)\end{array}$ & $\begin{array}{c}7.609 \\
(11.888)\end{array}$ \\
\hline $\begin{array}{l}\mathrm{T}_{4}-(\mathrm{R}+\mathrm{T}) \\
(3 / 18 \times 3.0 \mathrm{~m})\end{array}$ & $\begin{array}{c}0.903 \\
(1.389)\end{array}$ & $\begin{array}{c}0.106 \\
(0.162)\end{array}$ & $\begin{array}{c}0.407 \\
(0.625)\end{array}$ & $\begin{array}{c}1.572 \\
(2.418)\end{array}$ & $\begin{array}{c}1.212 \\
(1.864)\end{array}$ & $\begin{array}{c}1.338 \\
(2.058)\end{array}$ & $\begin{array}{c}0.794 \\
(1.222)\end{array}$ & $\begin{array}{c}0.912 \\
(1.403)\end{array}$ & $\begin{array}{c}0.457 \\
(0.702)\end{array}$ & $\begin{array}{c}0.103 \\
(0.158)\end{array}$ & $\begin{array}{c}7.804 \\
(12.006)\end{array}$ \\
\hline $\begin{array}{l}\mathrm{T}_{5}-(\mathrm{R}+\mathrm{T}) \\
(10.0 \times 5.0 \mathrm{~m})\end{array}$ & $\begin{array}{c}1.001 \\
(1.668)\end{array}$ & $\begin{array}{c}0.103 \\
(0.172)\end{array}$ & $\begin{array}{c}0.331 \\
(0.551)\end{array}$ & $\begin{array}{c}1.494 \\
(2.490)\end{array}$ & $\begin{array}{c}1.048 \\
(1.746)\end{array}$ & $\begin{array}{c}1.370 \\
(2.283)\end{array}$ & $\begin{array}{c}0.744 \\
(1.240)\end{array}$ & $\begin{array}{c}.940 \\
(1.566)\end{array}$ & $\begin{array}{c}0.396 \\
(0.659)\end{array}$ & $\begin{array}{c}0.103 \\
(0.172)\end{array}$ & $\begin{array}{c}7.531 \\
(12.551)\end{array}$ \\
\hline $\begin{array}{l}\mathrm{T}_{6}-\text { Pure tea } \\
(1.0 \times 0.6 \mathrm{~m})\end{array}$ & $\begin{array}{c}0.718 \\
(0.718)\end{array}$ & $\begin{array}{c}0.217 \\
(0.217)\end{array}$ & $\begin{array}{c}0.593 \\
(0.593)\end{array}$ & $\begin{array}{c}2.206 \\
(2.206)\end{array}$ & $\begin{array}{c}1.934 \\
(1.934)\end{array}$ & $\begin{array}{c}2.439 \\
(2.439)\end{array}$ & $\begin{array}{c}1.461 \\
(1.461)\end{array}$ & $\begin{array}{c}2.061 \\
(2.061)\end{array}$ & $\begin{array}{c}0.904 \\
(0.904)\end{array}$ & $\begin{array}{c}0.300 \\
(0.300)\end{array}$ & $\begin{array}{c}12.833 \\
(12.833)\end{array}$ \\
\hline
\end{tabular}

Note : Figures given in the parentheses is yield of green tea leaf ('000 kg/ha) at $100 \%$ plant population

Table.4 Remunerative index, mortality of rubber plants, plant population/ha of rubber and tea and infestation by red spider mite

\begin{tabular}{|c|c|c|c|c|c|}
\hline Treatments & $\begin{array}{l}\text { Remunerative } \\
\text { Index }\end{array}$ & $\begin{array}{l}\text { Mortality of } \\
\text { Rubber plants } \\
(\%)\end{array}$ & $\begin{array}{l}\text { Number of } \\
\text { rubber } \\
\text { plants/ha }\end{array}$ & $\begin{array}{l}\text { Number } \\
\text { of tea } \\
\text { plants/ } \\
\text { ha }\end{array}$ & $\begin{array}{l}\text { Average } \\
\text { number of red } \\
\text { spider mite/tea } \\
\text { leaf }\end{array}$ \\
\hline $\begin{array}{l}T_{1} \text { - Pure rubber } \\
(5.0 \times 5.0 \mathrm{~m})\end{array}$ & ---- & 6.36 & $\begin{array}{c}400 \\
(100 \%)\end{array}$ & ---- & ---- \\
\hline $\begin{array}{l}T_{2}-(R+T) \\
(10.0 \times 2.5 \mathrm{~m})\end{array}$ & 1.57 & 11.25 & $\begin{array}{c}400 \\
(100 \%)\end{array}$ & $\begin{array}{l}10020 \\
(60 \%)\end{array}$ & 31.4 \\
\hline $\begin{array}{l}\mathrm{T}_{3}-(\mathrm{R}+\mathrm{T}) \\
(12.0 \times 2.5 \mathrm{~m})\end{array}$ & 1.71 & 9.75 & $\begin{array}{c}360 \\
(90 \%)\end{array}$ & $\begin{array}{l}10688 \\
(64 \%)\end{array}$ & 37.3 \\
\hline $\begin{array}{l}\mathrm{T}_{4}-(\mathrm{R}+\mathrm{T}) \\
(3 / 18 \times 3.0 \mathrm{~m})\end{array}$ & 1.60 & 8.01 & $\begin{array}{c}330 \\
(82.5 \%)\end{array}$ & $\begin{array}{l}10855 \\
(65 \%)\end{array}$ & 43.2 \\
\hline $\begin{array}{l}\mathrm{T}_{5}-(\mathrm{R}+\mathrm{T}) \\
(10.0 \times 5.0 \mathrm{~m})\end{array}$ & 1.94 & 15.10 & $\begin{array}{c}200 \\
(50 \%)\end{array}$ & $\begin{array}{l}10020 \\
(60 \%)\end{array}$ & 35.7 \\
\hline $\begin{array}{l}\mathrm{T}_{6}-\text { Pure tea } \\
(1.0 \times 0.6 \mathrm{~m})\end{array}$ & --- & ---- & ---- & $\begin{array}{c}16667 \\
(100 \%)\end{array}$ & 57.3 \\
\hline $\mathrm{CD}(\mathrm{p}=0.05)$ & & 6.43 & & & 10.7 \\
\hline
\end{tabular}


Fig.1 Effect of rubber+tea intercropping on girth of rubber \& tea and yield of tea

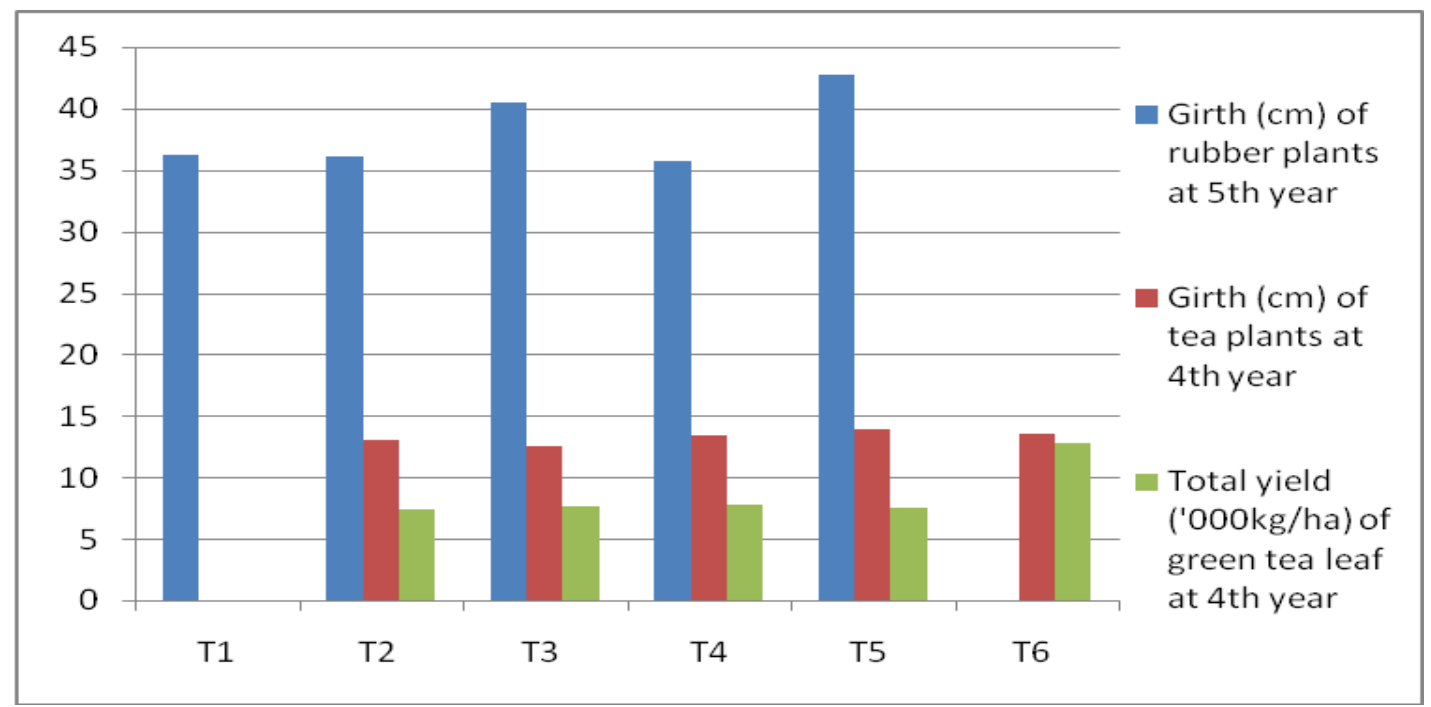

Fig.2 Effect of rubber+tea intercropping on remunerative index, mortality of rubber plants and infestation by red spider mite on tea

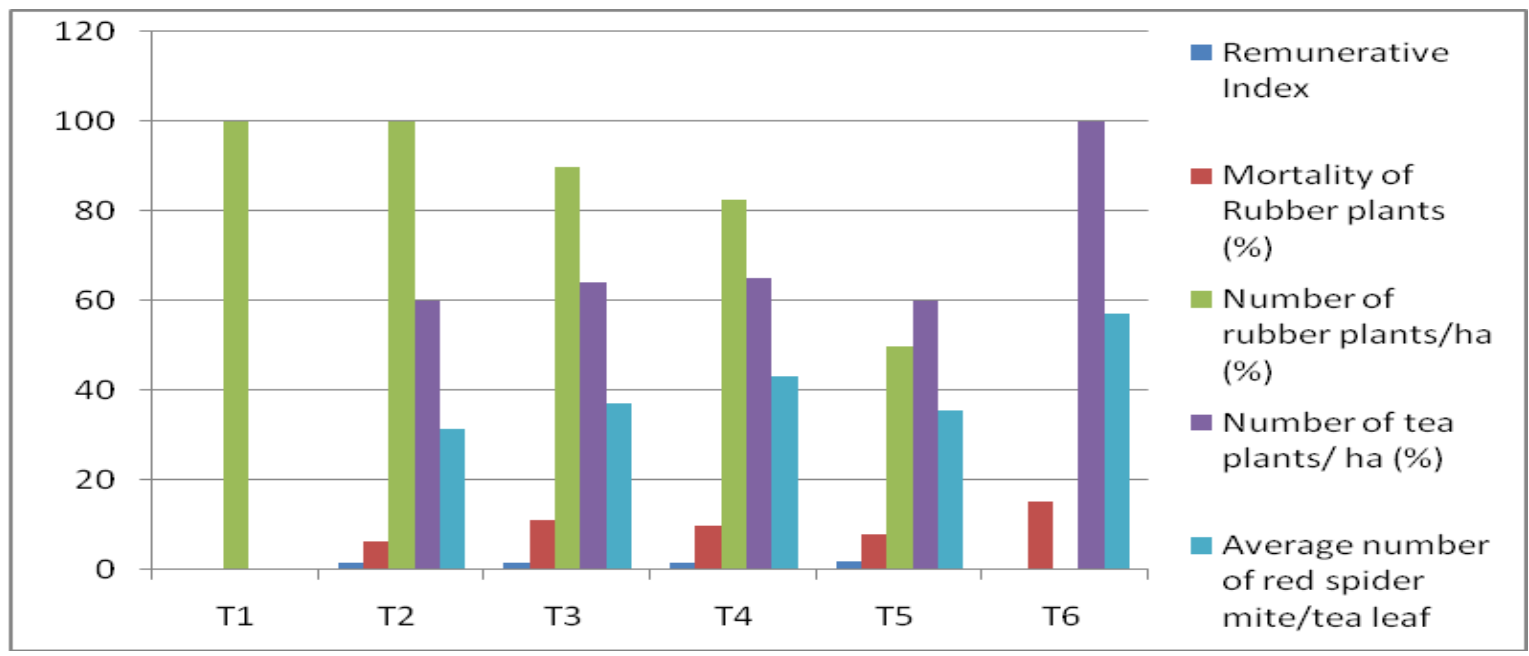

On the basis of findings of this experiment, it can be concluded that tea can successfully and profitably be grown as intercrop in between the inter-row spaces of rubber by changing in the crop geometry during immature phase of rubber with additional benefit of less infestation of red spider mite.

\section{Acknowledgement}

The author is grateful to Dr. N.M. Mathew, the then Director, RRII; Dr. James Jacob,
Director, RRII, Dr. Jacob Kuruvila (retired) for their valuable suggestion and guidance. My special thanks to Sri K.G. Vijayan, Sri J.P. Das, Sri P.K. Balakrishnan, Sri R. Mondal and Sri Jiten Saibo, RES, Nagrakata for their cooperation in different ways.

\section{References}

Choudhury, P., Dutta, B.K., and Bhattacharjee, P.C. (2006). Some ecological factors on population 
dynamics of red spider mite (Oligonychus coffeae) and their control in the agro-ecosystem of Barak valley, Assam (India). IJTS 5 (3\&4): 29-39.

Gomez, K.A. and Gomez A.A. (1984).Statistical procedures for agricultural research. John Willey and Sons, New York.

Kakaty, B.M., Chakrabarty, B. K. and Thakur, A. C. (2002). Multistoried cropping in bearing and pre-bearing arecanut plantations in Assam. Journal of Plantation Crops. 2002, 30
(2): 33-38.

Rubber Statistical News (monthly: December2004; 63 (7). The Rubber Board.

Wijesuriya, Wasana and Thattil, R.O. (2001). Methods of data analysis for intercropping systems under rubber. Journal of Rubber Research Institute of Srilanka, 84: 39-49.

Willey, R. W. and Osiru, D.S. (1972). Studies on mixture of maize and beans (Phaseolus vulgaris) with particular reference to plant population. Journal of Agricultural Science, Cambridge. 79: 519-529.

\section{How to cite this article:}

Singh, R.S., T. Gohain, S. Meti, D. Choudhuri, R.P. Singh, M.A. Nazeer and Jacob, J. 2019. Feasibility of Rubber+Tea Intercropping during Immature Phase of Rubber. Int.J.Curr.Microbiol.App.Sci. 8(03): 1873-1879. doi: https://doi.org/10.20546/ijcmas.2019.803.222 